\title{
Aligning the contents of curriculum of undergraduate medical education in Bangladesh with health related targets of Sustainable Development Goals (SDG).
}

SMM Saleh Bhuiyan ${ }^{1}$, Md. Humayun Kabir Talukder ${ }^{2}$, Farhana Yasmin ${ }^{3}$, Farhan Saleh Bhuiyan ${ }^{4}$

\begin{abstract}
Introduction: This descriptive type of cross sectional study was conducted to assess teachers' views regarding the alignment of contents of curriculum of undergraduate medical education in Bangladesh with the health related targets of Sustainable Development Goals.

Methods: The study was conducted during the period of July 2018 to June 2019. The study used standardized pre-tested instruments. Convenience sampling technique was employed to include 04 public and 04 private medical colleges, of which 05 were located in Dhaka city and 03 were located outside Dhaka city. Data were collected from 123 faculty members by using self-administered semi-structured questionnaire and from 25 Key informants by using in-depth Interview schedule. Data entry and analysis was done using SPSS 19.0.
\end{abstract}

Results: Among 123 medical teachers $84(68.3 \%)$ opined inadequacy of contents about neglected tropical diseases, 97(78.9\%) about road traffic accidents, 103(83.7\%) about narcotic drug abuse, 93(75.6\%) about universal health coverage, 108(87.8\%) about sexual health care services, 97(78.9\%) viewed about tobacco control and 116(94.3\%) about early warning about national and global health risks.

Conclusion: To achieve the health related targets of SDG, the curriculum of undergraduate medical education should be reviewed with inclusion of relevant contents which will help students to achieve relevant competencies of SDGs.

Keywords: Alignment, Curriculum, Teacher, Under-graduate medical education, Sustainable Development Goals.

1. Dr. SMM Saleh Bhuiyan, Director, Shaheed Ziaur Rahman Medical College Hospital, Bogura,

2. Dr. Farhana Yasmin, Classified Specialist in Pathology, Armed Forces Institute of Pathology, Dhaka Cantonment

3. Dr. Farhan Saleh Bhuiyan, Postgraduate Trainee in Medicine, Dhaka Medical College Hospital, Dhaka

4. Professor Dr. Md. Humayun Kabir Talukder, Department of Curriculum Development and Evaluation, Centre for Medical Education, Mohakhali, Dhaka.

Address of correspondence : SMM Saleh Bhuiyan, Director, Shaheed Ziaur Rahman Medical College Hospital, Bogura

E-mail: emailzahir1990@gmail.com

Bangladesh Journal of Medical Education 2020; 11(2);Bhuiyan et al., publisher and licensee Association for Medical Education. This is an Open Access article which permits unrestricted non-commercial use, provided the original work is properly cited. 


\section{Introduction}

Curriculum is a formal plan of educational experiences and activities offered to a learner under the guidance of an educational institute (Harden, 1996).The contents of curriculum for undergraduate medical education must be prepared basing on need assessment, of which health need of the community and country is of paramount importance. The curriculum is a sophisticated blend of educational strategies, course content, learning outcomes, educational experiences, assessments, the educational environments and the individual students learning styles, personal time table and programme of work(Harden 2001). The curriculum is seen as covering not only what is taught but also how it is taught and learned, and how the learning is managed and over all learning environment (Harden 1986).

A curriculum is a vision and a road map to meet the academic objective (Vare et al.2017). Curriculum has been defined by Tanner and Tanner(1975 cited Bharvad, 2010) as the planned guided learning experience and intended learning outcomes formulated through a systematic reconstruction of knowledge and experiences under the auspices of school for the learner's continuous and willful growth in academic, personal and social competence (Bharvad 2010).
Evaluation of curriculum is an integral and essential part of the whole process of curriculum development. It is a continuous activity and not "tail-end-process". Evaluation and planning are complementary process which occurs almost simultaneously and continuously. Planning is made on the basis of evaluation and vice versa.

Medical education in developed and developing countries has undergone profound changes to keep pace with advancing public health needs and challenges (Mosaddek et al.2011). Medical education in Bangladesh also has been experiencing many changes and challenges (Majumder 2002). The updated undergraduate medical education curriculum 2012 is now implemented in all the medical colleges from session 20122013(BM\&DC 2012).

In Sept 2015, heads of the states and governments of 193 countries meet at UN headquarters in New York and agreed on a new generation of 17 Sustainable Development Goals (SDGs) with 169 targets to guide global development over the next 15 years till 2030 (SDGs and country process in Bangladesh, 2017).

To make the Curriculum of Undergraduate Medical Education of Bangladesh more effective, this study was an attempt to find out the alignment of various elements of this curriculum in relation to the health

Bangladesh Journal of Medical Education 2020; 11(2);Bhuiyan et al., publisher and licensee Association for Medical Education. This is an Open Access article which permits unrestricted non-commercial use, provided the original work is properly cited. 
related targets of Sustainable Development Goals (SDG) considering the views of teachers of some selected medical colleges

\section{Methods}

This was a descriptive type of cross sectional study (mixed methods). The study was conducted from July 2018 to June 2019. Convenience sampling technique were adopted. This study was conducted in selected 8 medical colleges and few institute/organizations of Bangladesh. The sample size were 148. Data was collected by documents review checklist by the researcher, Self-administered semistructured questionnaire from 123 medical teachers and In-depth interview schedule from 25 Key Informants. Teachers who teaches subjects relevant to health related targets of SDG were taken as study population. Accordingly teachers of Internal Medicine, Community Medicine, Psychiatry, Orthopedics, Obstetrics and Gynaecology and Pediatrics were respondents. In-depth interview was taken from 16 experienced teachers of selected and some Key Informants of different organization

medical colleges and also from $09 \mathrm{Key}$ Informants of various organizations and institutes. Data entry and analysis was done by computer.

\section{Results}

A total of 123 medical teachers participated in the study of which $75(61 \%)$ were male and $48(39 \%)$ were female. Out of 123 medical teachers, 25(20.9\%) were professor, 54(43.9\%) were associate professor, $40(32.5 \%)$ were assistant professor and $4(3.3 \%)$ were others. And $28(22.7 \%)$ were from the specialty of Medicine, 27(22\%) were Obstetrics and Gynaecology, 20(16.3\%) were Pediatrics, 20(16.3\%) were Community Medicine, 12(9.8\%) were Psychiatry, 16(13\%) were Orthopedics. Among the respondents, $71(57.7 \%)$ were from Govt. Medical colleges and $52(42.3 \%)$ were from the nongovt. medical colleges.

Table 1 Distribution of the respondent by their opinion regarding the adequacy of the content of curriculum in relation to health related targets SDG3 $(n=123)$

\begin{tabular}{|l|c|c|c|c|}
\hline \multicolumn{1}{|c|}{ Statement } & $\begin{array}{c}\text { Inadequate } \\
\mathbf{f}(\boldsymbol{\%})\end{array}$ & $\begin{array}{c}\text { Adequate } \\
\mathbf{f}(\boldsymbol{\%})\end{array}$ & $\begin{array}{c}\text { Overloaded } \\
\mathbf{f}(\boldsymbol{\%})\end{array}$ & $\begin{array}{c}\text { Not } \\
\text { applicable } \\
\mathbf{f}(\boldsymbol{\%})\end{array}$ \\
\hline Neglected tropical diseases & $84(68.3)$ & $32(26.0)$ & $0(0)$ & $07(5.7)$ \\
\hline Road traffic accidents & $97(78.9)$ & $21(17.1)$ & $0(0)$ & $05(4.1)$ \\
\hline Mental health & $81(65.9)$ & $38(30.9)$ & $0(0)$ & $04(3.3)$ \\
\hline Substance abuse & $87(70.7)$ & $31(25.2)$ & $0(0)$ & $05(4.1)$ \\
\hline
\end{tabular}

Bangladesh Journal of M edical Education 2020; 11(2);Bhuiyan et al., publisher and licensee Association for Medical Education. This is an Open Access article which permits unrestricted non-commercial use, provided the original work is properly cited. 
Original Article

\begin{tabular}{|l|c|c|c|c|}
\hline $\begin{array}{l}\text { Narcotic drug } \\
\text { abuse }\end{array}$ & $103(83.7)$ & $15(12.2)$ & $0(0)$ & $05(4.1)$ \\
\hline Harmful use of alcohol & $112(91.1)$ & $06(4.9)$ & $0(0)$ & $05(4.1)$ \\
\hline Sexual health-care services & $108(87.8)$ & $10(8.1)$ & $0(0)$ & $05(4.1)$ \\
\hline Reproductive health-care services & $98(79.7)$ & $18(14.6)$ & $0(0)$ & $07(5.7)$ \\
\hline Universal Health Coverage & $93(75.6)$ & $26(21.1)$ & $0(0)$ & $04(3.3)$ \\
\hline $\begin{array}{l}\text { Access to quality essential health- } \\
\text { care services }\end{array}$ & $113(91.9)$ & $07(5.7)$ & $0(0)$ & $03(2.4)$ \\
\hline $\begin{array}{l}\text { Access to safe, effective, quality } \\
\text { and affordable essential medicines } \\
\text { and vaccines for all }\end{array}$ & $106(86.2)$ & $14(11.4)$ & $0(0)$ & $03(2.4)$ \\
\hline Strengthen Tobacco control & $97(78.9)$ & $23(18.7)$ & $0(0)$ & $03(2.4)$ \\
\hline $\begin{array}{l}\text { Awareness of health financing } \\
\text { Recruitment, } \\
\text { training and retention of the health } \\
\text { workforce }\end{array}$ & $113(91.9)$ & $03(2.4)$ & $0(0)$ & $0(5.7)$ \\
\hline $\begin{array}{l}\text { Early warning of national and } \\
\text { global health risks. }\end{array}$ & $117(95.1)$ & $02(1.6)$ & $0(0)$ & $04(3.3)$ \\
\hline $\begin{array}{l}\text { Risk reduction and management of } \\
\text { national and global health risks. }\end{array}$ & $116(94.3)$ & $03(2.4)$ & $0(0)$ & $04(3.3)$ \\
\hline
\end{tabular}

\section{Discussion}

These study findings are basically based on the perceived views of medical teachers and Key Informants. This descriptive cross sectional study was conducted to collect views on some selected issues regarding the 'Curriculum for Under-graduate Medical Education in Bangladesh - Updated 2012' from teachers of different government and nongovernment medical colleges and some Key Informants of whom 123 were teachers and 25 Key Informants. Approximately 90\% of teachers who were served with questionnaire have responded to question.
Among the Key Informants all were responded well.

Study revealed that, out of 123 respondents, $97(78.9 \%)$ and $81(65.9 \%)$ opined that, contents related to road traffic accidents and neglected tropical diseases were inadequate. Key Informants of present study also opined that, contents related to road traffic accidents and neglected tropical diseases were inadequate. In current study, out of 123 respondents, $87(70.7 \%), 103(83.7 \%)$ and $112(91.1 \%)$ respondents opined that contents related substance abuse, narcotic drug abuse and harmful use of alcohol respectively were

Bangladesh Journal of Medical Education 2020; 11(2);Bhuiyan et al., publisher and licensee Association for Medical Education. This is an Open Access article which permits unrestricted non-commercial use, provided the original work is properly cited. 
inadequate. Key Informants of present study also opined the same.

Among 123 respondents, 108(87.8\%) and 98(79.7\%) opined that contents related to Sexual health-care services and Reproductive health-care services respectively were inadequate. Similar study done by Alam AY et al.(2013) showed that, contents related to reproductive health care services, Sexually Transmitted Diseases(STD) and Sexually Transmitted Infection(STI) were adequate as opined by $88 \%$ respondents.

In this study, Out of 123 respondents, 93(75.6\%),113(91.9\%) and 106(86.2\%) opined that, contents related to Universal health coverage, access to quality essential health-care services and access to safe, effective, quality and affordable essential medicines and vaccines for all respectively were inadequate.

Among 123 respondents, 97(78.9\%) and $99(80.5 \%)$ opined that, contents related to strengthening tobacco control was inadequate. Out of 123 respondents,

\section{References}

Alam AY, Abbas SM, Mallik MR,2013, Public health and the undergraduate medical curriculum: Are we preparing physicians for the $21^{\text {st }}$ century, Journal of Pakistan Medical Association, October 2013,vol.63, No.10, pp 1241-47.
$113(91.9 \%)$ opined that contents related to awareness of health financing, recruitment, development, training and retention of the health workforce were inadequate. Documents review by the researcher in present study revealed no such contents existing in curriculum. Out of 123 respondents $116(94.3 \%)$ opined that contents related to risk reduction and management of national and global health risks were inadequate. The study findings are consistent with the findings of similar study conducted by Mosaddek et al. (2011).

\section{Conclusion}

The present study shows, there are some inconveniences experienced by both medical teachers \& Key Informants and observations regarding the amount of contents in different subjects to achieve the health related targets of SDG. Therefore to achieve the health related targets of SDG, the curriculum should be reviewed with inclusion of relevant contents which will help students to achieve relevant competencies.

Bharvad AJ 2010. Curriculum Evaluation. International Research Journal, vol. 1, no. 2.

BM\&DC 2012. Curriculum for Undergraduate Medical Education in Bangladesh-Updated 2012. Bangladesh Medical and Dental Council, Dhaka, Centre for Medical Education.

Bangladesh Journal of Medical Education 2020; 11(2);Bhuiyan et al., publisher and licensee Association for Medical Education. This is an Open Access article which permits unrestricted non-commercial use, provided the original work is properly cited. 
Harden RM, Sowden S, Dunn WR 1984. Educational strategies in curriculum development: the ...spices model. Medical Education, vol. 18, pp. 284-29.

Harden RM, Laidlaw JM, Ker JS, Mitchell HE 1996. Task based learning: an educational strategy ...for undergraduate, postgraduate and continuing medical education, Part 1. Medical Teacher, vol._18, no.1.

Health in the Sustainable Development Goals, World Health Organization, Office for the South East Asia, 2017

Majumder MAA 2002. A review of the undergraduate medical curriculum in Bangladesh. ...Bangladesh Medical Journal, vol. 31, pp. 47-49.
Mosaddek ASM, Islam MJ, Rahman MF, Chaudhury HS, Parvin R, Khanom M 2011. Present status of implementation of undergraduate curriculum of Bangladesh in selected private medical colleges: Teachers perspectives. South East Journal of Public Health, vol. 1, pp. 73-...74.

Prideaux D 2003. ABC of learning and teaching in medicine curriculum design. BMJ, vol. 326, ...pp. 268-270.

Vare VA, Kurle DG, Bagle TR, Hire RC, Shukla AO 2017. Evaluation of teaching methods in ...Pharmacology among MBBS students. International Journal of Basic and Clinical ...Pharmacology, vol. 6, no. 6, pp. 13521353.

Bangladesh Journal of Medical Education 2020; 11(2);Bhuiyan et al., publisher and licensee Association for Medical Education. This is an Open Access article which permits unrestricted non-commercial use, provided the original work is properly cited. 